Portland State University

PDXScholar

\title{
The Impact of Corruption on the Timing and Mode of Entry by U.S. Firms in China
}

Jacob Billings

Portland State University

Follow this and additional works at: https://pdxscholar.library.pdx.edu/econ_honorstheses

Part of the Economic History Commons, and the Economic Theory Commons Let us know how access to this document benefits you.

\section{Recommended Citation}

Billings, Jacob, "The Impact of Corruption on the Timing and Mode of Entry by U.S. Firms in China" (2009). Economics Undergraduate Honors Theses. 3.

https://pdxscholar.library.pdx.edu/econ_honorstheses/3

This Thesis is brought to you for free and open access. It has been accepted for inclusion in Economics Undergraduate Honors Theses by an authorized administrator of PDXScholar. Please contact us if we can make this document more accessible: pdxscholar@pdx.edu. 


\title{
The Impact of Corruption on the Timing and Mode of
}

\author{
Entry by U.S. Firms in China
}

\author{
Jacob Billings
}

\section{Introduction}

Since 1979 when China opened its economic borders, it has seen an influx of foreign direct investment that gradually snowballed into enormous annual inflows of capital.

Researchers have taken advantage of this event as an incredibly useful testing ground of theories regarding FDI. Using this new data from China, along with data from countries already open to outside investment, many variables, such as GDP, wage, and distance, have been found to consistently correlate in one way or another to particular aspects of FDI inflow, including amount, location, timing, and type.

One such variable that has had some attention is corruption. While it has been well established that corruption in general is a deterrent to FDI inflows, little else can be confidently said about its effect on FDI. This paper is an attempt to at least get a sense of what the effect of corruption might be on two aspects of FDI: timing and type.

These are both important effects to know about, certainly at least from the standpoint of governments. If it could be shown that firms are less hesitant to invest, or more willing to commit high equity type investments when corruption is low, governments, particularly those in 
developing countries that rely on FDI, may be persuaded to make more of an effort to fight corruption and improve governance.

This paper will describe two models, one measuring the effect of corruption on how quickly a firm chooses to invest in China, and another measuring the effect of corruption on what sort of investment the firm makes. The remainder of the paper is divided into four parts: A survey of previous literature on the subject, a description of the empirical framework (itself subdivided into parts, discussions of the dependent variables under consideration, the corruption measures used, the control variables, and the source of data), a report of the empirical results, and finally the conclusion.

\section{Previous Literature}

\section{General Determinants of FDI in China}

There are four basic aspects to consider under the umbrella of FDI: amount, mode, timing, and location. Depending on which paper one reads, the determinants considered have either significant or insignificant impact, but when there is significance, signs usually agree. For example, Sun et al (2002) find wages, infrastructure, market demand and size, labor quality and cost, political risk, openness to outside trade, and under particular time ranges, GDP, to be important variables, while Quazi (2007) agrees generally, except that significance was not found for human capital (analog to labor quality) or infrastructure. In particular, Quazi found that economic freedom has a large impact on FDI inflows to East Asian countries. Another factor that doesn't seem obvious is the finding by Liu (2008) that Chinese FDI inflow is greater from countries that are not members of the Asia-Pacific Economic Cooperation. 
Findings for determinants of mode choice are somewhat slim. Chen (2006) found that firms are more likely to choose greenfield investment when they have a lot of firm-specific assets (such as knowledge) that may be difficult to transfer to an operation already running. Attacking the question at a different angle, Shapiro et al (2007) studied whether location determinants differ by entry mode. Location choice for equity joint ventures were affected significantly by wage, FDI stock, education, and presence of special economic zones, while cooperative joint ventures only saw significance from the economic zones, and wholly owned enterprises saw significance only in FDI stock.

On that note, papers studying locational determinants of FDI to China are quite common, and give myriad findings on important variables: proximity to markets and suppliers (Amiti and Javorcki, 2005), governance quality and corruption (Cole et al, 2009), labor quality, economic zones, and distance (Gao, 2005), patent certification volume, share of state-owned business, GDP, wage, and road density (Kawai, 2009). Again, not every study agrees on which variables are significant, but when they do, the signs are usually the same.

Research on investment timing, at least in China, is even slimmer than that for mode choice. However, one paper by Raff and Ryan (2008) finds various firm characteristics that affect investment timing - size, productivity, and R\&D intensity were found to be correlated with a greater eagerness to invest more quickly, while a lack of diversity in a firms product line is associated with a more conservative approach.

\section{Institutional determinants of FDI}

Institutional characteristics of FDI's host countries is a popular line of inquiry, inquiry which has confirmed intuitive notions of how "better" institutions should affect FDI. In a more 
general example, Aizenman and Spiegel (2002) analyze an expert survey-based measure of "institutional efficiency" in its effect on investment composition, and find that the ratio of FDI to domestic investment rises with greater efficiency. Similarly, Benassy-Quere et al (2007) find that "quality of bureaucracy," is an important factor in FDI inflow.

More specific research includes the finding by Fung et al (2005) that market reforms, as proxied by proportion of state-owned enterprises in the various Chinese provinces, is a more important determinant, at least in China, of FDI inflow. Hong's 2008 paper finds that accession into the World Trade Organization fundamentally changed the way FDI inflows to China were determined - from high reliance on GDP, university count, and road density, to wage level and agglomeration.

One interesting paper by Havrylchyk and Poncet (2007) posits that distortions caused by Chinese policies, in particular state restrictions on credit access and proportion of state-owned banking, can increase FDI inflow, as such institutions can hamper domestic competition more severely than foreign competition. The data studied seem to support this position.

\section{Corruption as a determinant}

There is almost unanimous agreement in the literature that in the broadest sense, corruption is a deterrent to foreign investment. Egger and Winner (2006) proposed two opposing forces of corruption, referred to as "grabbing hand" and "helping hand," which deter and encourage investment, respectively. Their finding was that the "grabbing hand" overpowered the "helping hand" and realized an overall deterrence. This general result is agreed upon in all literature (e.g. Globerman and Shapiro, 2003) that employs corruption as an independent variable, in addition to the other dimensions of effect corruption has been found to have. 
For instance, Cuervo-Cazurra (2006) finds that not only is corruption in general important, but also the differential in the corruption level between investor country and host country. Interestingly, it turns out that countries which themselves have high levels of corruption send relatively more FDI to high-corruption hosts. Habib and Zurawicki (2002) agree with this result.

In a finer examination specifically on corruption in China, Cole et al (2009) proxy for anti-corruption efforts in the various provinces of China using number of corruption investigations per capita. This paper holds the distinction of being one of the only attempts to study the effect of corruption in China on FDI on the provincial level, and unsurprisingly finds a positive correlation between anti-corruption efforts and FDI levels. While corruption investigations may be an unsatisfactory proxy for corruption level, it could easily be argued that it is the perception of corruption that affects a firm's willingness to invest, and corruption investigations may have a significant effect on those perceptions.

Straub (2008) attempts to find the difference in effect on FDI between bureaucratic and political corruption, vis-à-vis their impact on investment through FDI vs. "arm's length" investment (that is, investment with looser control rights endowed to the investor, like license agreements). The author finds that bureaucratic corruption favors non-FDI investment, but at a magnitude that falls off as the level of corruption increases. Meanwhile, political corruption also favors non-FDI investment, but only very weakly unless interacted with a political risk measure.

Globerman and Shapiro's 2003 paper on how governance and infrastructure affect FDI perhaps most closely sets precedent for the subject of this paper. It is broader, in that it addresses not just corruption, but economic openness, government effectiveness, contract enforcement, and 
even origin of legal system in FDI host country. It is also based on a panel of several countries instead of just China. In another sense it is narrower, as it compares determinants between industry, but restricts itself to comparing high-tech industry to all other industry, finding that high-tech industries are more positively affected by work force education level. The study uses a two stage model; a probit for likelihood of receiving FDI, followed by a regression estimating determinants on amount of FDI received. The general finding is that there is a certain threshold of governance quality below which a host country is unlikely to receive any FDI at all, whereas countries which have received FDI are more likely to see a greater volume accompanying greater economic openness and government effectiveness, and lower corruption.

\section{Empirical Framework}

This section will describe two empirical models. The first model is a standard ordinary least squares regression to find the correlation between national-level corruption in China and the timing of investments in the various Chinese provinces by US firms. Specifically the dependent variable will be the log of days passed between 1980, when China was first open to foreign investment, and the first investment made in China by the firm represented by a given observation. The independent variables are, first, a measure of corruption, and then a battery of provincial variables, firm-level variables, and other control variables.

The second is a probit model intended to measure the correlation between the same measures of corruption and the likelihood of a firm, which has already decided to invest in China, to invest in one of four so-called "high-equity" modes of investment, versus one "lowequity" type of investment. The high equity modes are as follows: new plants, acquisitions, joint ventures, and wholly-owned subsidiaries. Regional sales offices are regarded as low-equity 
investments. Agreements for sales contracts and licensing agreements are also considered lowequity investment, but are not present in the sample.

\section{Timing of Investment}

The variable used to measure timing of investment is the log of days passed between January 1, 1980 and the date of the observed investment. The following graph demonstrates the general shape of investment timing:

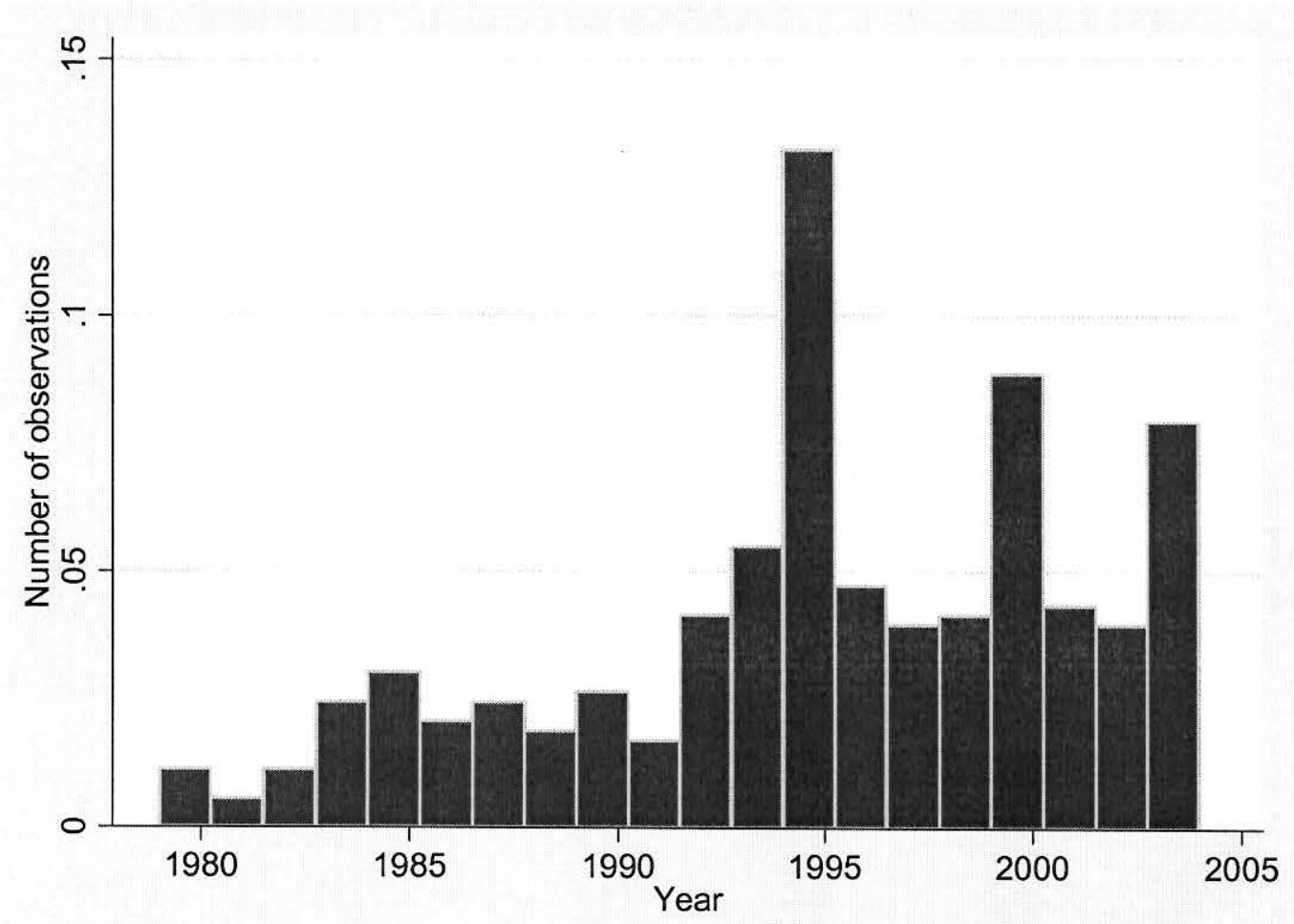




\section{Equity Type}

The sample of investment observations contains data on which of six types of investment occurred: Wholly owned subsidiary, joint venture, new plant, acquisition, or sales office. The following chart shows the overall distribution of these types in the sample:

\section{Entry Patterns: Mode of Entry}

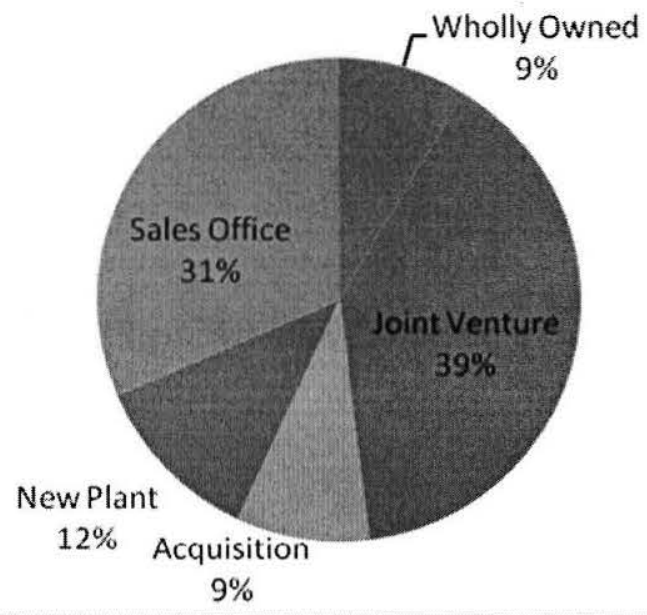

This chart only gives a sense of how firms invested within a 25 year period. The next graph shows the proportion over time of investments that were one of the first four types:

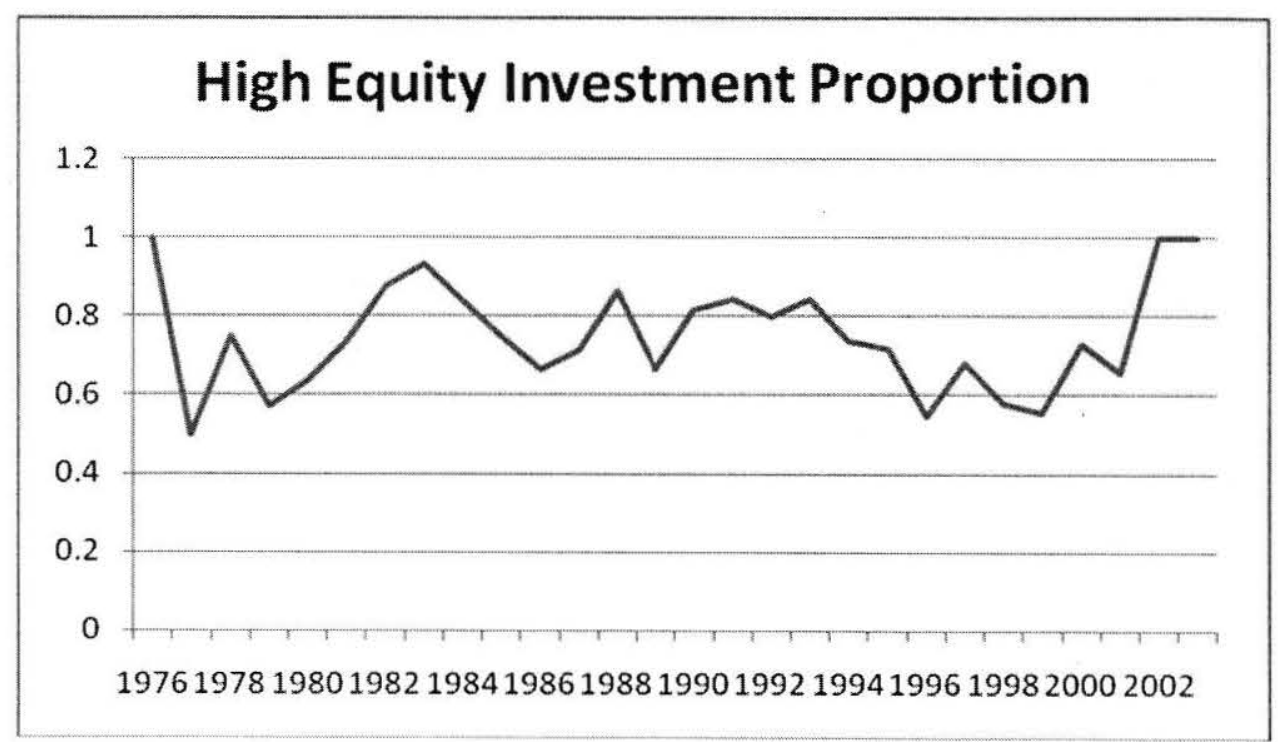




\section{What Measure of Corruption?}

While it must be agreed that corruption, however defined, must have some effect on economic behavior, deciding to use it as a statistical variable begs the question: how do we measure it? It seems to me that there are two options facing the researcher. One is to use a proxy variable, as Cole et al did in their 2009 paper. Their particular method of using number of corruption cases per capita by province is appealing, but presents problems both theoretical and practical. Theoretically, there is the problem of whether to consider a high number of cases a sign of rampant corruption or of a low tolerance of corruption (the paper in question treats it as the latter).

As an analogy, consider how potential homebuyers might react to a high level of theft convictions in a particular neighborhood. Perhaps a savvy homebuyer would anticipate increased property values due to thieves being deterred by the crackdown, but it seems unreasonable to say confidently that buyers at large would have this reaction.

The other option available is a corruption index. There are at least three such indices available, all three of which were utilized during this experiment. The three are as follows: The World Bank's Worldwide Governance Indicators Project (1996-2005), which includes an index measuring "control of corruption," Transparency International's corruption perceptions index (1980-2005), and Political Risk Services Group's quality of government index (1984-2005), which incorporates a corruption measure.

It is important to note that all three of these indices are based on surveys given to various experts in economics, politics, and industry, and are thus based on subjective perceptions of corruption rather than direct, tangible measurements. However, if they do accurately measure 
perceptions of corruption, then they can still be considered useful, as it could be argued that perceptions of corruption are what drive the behavior of firms considering investing, rather than the corruption level itself.

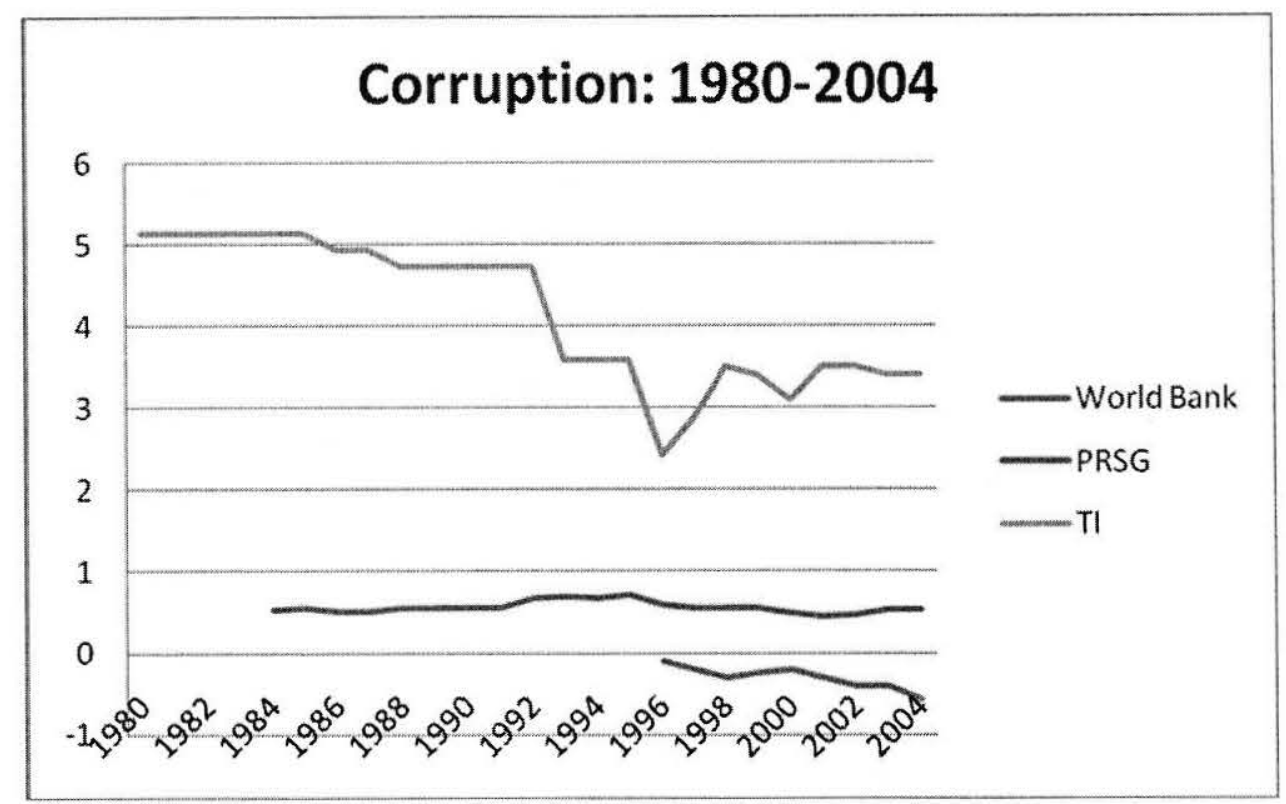

It appears at first glance that the three indices exhibit significantly different trends. PRSG essentially has no trend, while World Bank has a gentle downward trend, and Transparency International has a slow downward trend until the mid-90s, when it experiences a sharp dropoff, followed by somewhat chaotic swings through to the 2000s.

Below is a correlation table for the three indices under consideration:

\begin{tabular}{llll}
\hline & TI & PRS & WB \\
\hline TI & 1.0 & & \\
PRS & 0.2391 & 1.0 & \\
WB & -0.7274 & 0.4294 & 1.0 \\
\hline
\end{tabular}


As can be seen, noting that all three indices assign a higher score to "better" corruption levels, the three indices that purport to measure roughly the same thing have poor to strikingly bad (i.e. incorrectly signed) correlation. At best this means that only one of them is worth considering, and at worst it means that all three are essentially worthless, at least without more observations. During the course of the experiment, it became apparent that both the World Bank's and Political Risk Services Group's indices suffered severe multicollinearity in the equity type probit, so were dropped in favor of Transparency International's Index. In the timing of entry regression, results for all three indices will be presented.

\section{National/Province Level Control Variables}

SEZ: Many previous papers have utilized presence or number of Special Economic Zones (which in this paper refer also to open coastal cities and free trade zones) as a proxy for economic openness of a Chinese province. For example, Fung et al found in 2005 that number of such zones is positively correlated to amount of FDI flowing into a province.

For timing of investment, I formulated the variable as a dummy indicating that the investment took place within one year of the establishment of an SEZ in the given province. The sign on this variable may go either way theoretically, but it seems reasonable to say that a firm which invests only when the institutional business climate improves is one that invests more cautiously, and thus will wait longer in general to invest. Therefore the predicted sign on this variable is positive.

For type of investment, I formulated the variable as a dummy simply indicating that at least one SEZ was present in the province at the time of investment. I predict that SEZ presence 
will encourage firms to make more high-equity investments, so I predict the variable's sign to be positive.

Education: This is a standard control variable to proxy for human capital, and is widely found to have a positive relationship with FDI inflows in general, particularly in Gao's 2005 paper. I predict that education, here formulated as enrollment levels in secondary schools, will have a negative relationship with timing and a positive relationship with high equity investment.

Highway Density: This is also a standard control variable, which can proxy for both infrastructure and ease of commerce. Almost all papers investigating FDI include highway density or something like it (e.g. rail density) as a control. I predict that highway density will have a negative correlation with timing, and a positive correlation with high equity investment. Note that this variable is de-trended for use in the timing model.

Rural Electricity: This variable, which measures consumption of electricity in rural areas of the provinces, is used as a proxy for infrastructure. This variable has not been used in any previous literature on FDI in China that I am aware of. I predict that this too will have a negative correlation with timing and a positive correlation with high equity investment.

GDP per Capita: GDP or GDP per capita is a standard control variable used in virtually every single empirical analysis of FDI patterns. It is theoretically linked to greater FDI inflows and empirically this has been borne out. Likewise I predict that GDP per capita will be negatively correlated with timing, and positively correlated with high equity investment. Note that the variable is de-trended for use in the timing model.

Wages: This too is a boilerplate control variable, with higher wages almost always corresponding to deterred investment. That being the case, I predict wages to be positively 
correlated to timing of investment. Correlation with equity type is a little more difficult to

discern. It may be the case that higher wages (and thus greater disposable income) could attract more sales offices, while high-equity export oriented firms may be drawn to low wage areas. I will provisionally predict that wages will be negatively correlated to high equity investment. Note that the variable is de-trended for use in the timing model.

\section{Firm-Level Control Variables}

Size: This variable measures firm size by market cap, and is predicted to be correlated negatively with timing, and positively with high equity.

Debt: This variable is expected to correlate positively with timing and negatively with high equity.

Market to Book Ratio: This variable can be seen as a measure of opportunity of expansion of a firm, as seen by investors. Firms with such opportunity may be considered, all else equal, to have more opportunity to exercise caution in regard to foreign investment, and will wait longer to invest in China.

Sales Growth: Similarly to market to book, firms with high sales growth in their current markets have less incentive to establish a presence in China, all else equal, so this variable is expected to be positively correlated to timing.

$R \& D$ Intensity: This variable is formulated as amount of $\mathrm{R} \& \mathrm{D}$ expenditure scaled by total sales. Firms with a high R\&D intensity have a high level of intangible assets, and as such will be more cautious about investing in a new market, and in turn investing with high equity. 
Thus the variable is expected to have a positive relation with timing and a negative relation with high equity.

Advertising Intensity: This variable is formulated as amount of advertising expenditure scaled by total sales. Firms with high advertising intensity can be said to be highly concerned with market share, and as such can be expected to hurry to new markets. Thus the variable is expected to be negatively correlated with timing.

Employee Intensity: This variable is formulated as employment level scaled by total sales. Even for provinces with high wages relative to the rest of China, wages will still be significantly lower than those in the U.S. So firms with high employee intensity can be expected to be eager to set up shop in China, as their costs could be drastically lowered. The variable is expected to be negatively correlated with timing of investment.

Manufacturing Dummy: This variable is formulated as a one if the given investment for the observation is classified as manufacturing-related, and zero otherwise (or if unknown).

Finally, both models include a regional dummy variable and the equity model includes a year dummy variable to capture unaccounted for macro-economic effects. See Table $\mathbf{1}$ for a concise description of variables. 


\section{The Models}

The final forms of the models will be as follows, for timing:

$$
\begin{aligned}
& \mathrm{ToE}_{i}=\beta_{0}+\beta_{1} \operatorname{CORR}_{i} \beta_{2} \operatorname{SIZE}_{i}+\beta_{3} D E B T_{i}+\beta_{4} M T B_{i} \\
& +\beta_{5} \operatorname{SALESGR}_{i}+\beta_{6} R \& D_{i}+\beta_{7} A D V_{i} \\
& +\beta_{8} E M P L_{i}+\beta_{9} M F G_{i}+\beta_{10} W A G E_{i} \\
& +\beta_{11} G D P_{i}+\beta_{12} H I G H W A Y_{i} \\
& +\sum_{k=13}^{k=19} \beta_{k}(\text { REGION })+\epsilon_{i}
\end{aligned}
$$

Where ToE $=\operatorname{Ln}($ Entry date $-\operatorname{Jan} 01,1980)$.

And for equity:

$$
\begin{array}{rl}
\mathrm{MoE}_{i}=\beta_{0}+\beta_{1} & C O R R_{i}+\beta_{2} \operatorname{SIZE}_{i}+\beta_{3} D E B T_{i}+\beta_{4} M T B_{i} \\
& +\beta_{5} S A L E S G R_{i}+\beta_{6} R \& D_{i}+\beta_{7} A D V_{i} \\
& +\beta_{8} E M P L_{i}+\beta_{9} E N R O L L_{i}+\beta_{10} \text { WAGE }_{i} \\
& +\beta_{11} G D P_{i}+\beta_{12} H_{I G H W A Y_{i}} \\
& +\beta_{13} \text { RURALELEC } i+\beta_{14} S E Z_{i} \\
& +\sum_{k=15}^{k=21} \beta_{k}(\text { REGION })+\sum_{k=22}^{k=45} \beta_{k}(\text { YEAR })+\epsilon_{i}
\end{array}
$$

Where $\mathrm{MoE}=1$ if equity type is joint venture, wholly-owned subsidiary, acquisition, or new plant, and 0 if it is a sales office. 


\section{Data}

All firm-level data comes from INSERT SOURCE HERE via Wooster (2010), who collected and organized all the observations. All province level data is from China Data Online, with the exception of SEZ establishment information, which was procured from various internet sources. Corruption measures are alternatively from the World Bank Governance Indicators Project, Transparency International, and Political Risk Services Group. Below are tables of the descriptive statistics:

\begin{tabular}{|cccccc}
\hline Variable & Observations & Mean & Std. Dev. & Min. & Max. \\
\hline Size & 423 & 7.00 & 1.718 & 1.447 & 12.575 \\
Debt & 423 & 0.165 & 0.163 & 0 & 1.159 \\
MTB & 423 & 2.248 & 2.589 & 0.132 & 34.321 \\
\hline Sales Grth & 380 & 0.176 & 1.183 & -0.977 & 19.460 \\
R\&D & 423 & 0.067 & 0.108 & 0 & 0.880 \\
\hline Advertising & 423 & 0.011 & 0.026 & $1.80 \mathrm{E}-9$ & 0.192 \\
\hline Employee & 423 & 0.007 & 0.006 & $9.37 \mathrm{E}-8$ & 0.049 \\
\hline
\end{tabular}

\begin{tabular}{|llllll|}
\hline Variable & Observations & Mean & Std. Dev. & Min & Max \\
\hline Highway Density(de-trended) & 331 & 3.858 & 1.352 & 0.348 & 5.931 \\
2ndary Schl. Enrollment & 331 & 171.193 & 152.314 & 2.08 & 633.96 \\
$\begin{array}{l}\text { Rural Electricity Consumption } \\
\text { Wage (de-trended) }\end{array}$ & 331 & 90.898 & 104.219 & 7.68 & 714.25 \\
GDP per Capita (de-trended) & 331 & 1.372 & 0.360 & 0.030 & 1.975 \\
\hline Corruption Index & 331 & 2.591 & 1.202 & 0.500 & 5.72 \\
\hline World Bank & Observations & Mean & Std. Dev. & Min & Max \\
PRSG & 182 & -2.954 & 0.126 & -0.58 & -0.1 \\
Transparency Intl. & 346 & 0.578 & 0.083 & 0.444 & 0.722 \\
\hline
\end{tabular}




\section{Results}

The following table reports the results for an OLS regression using 4 models: model (1)

with no corruption variable, model (2) with the PRSG corruption variable, model (3) with the World Bank variable, and (4) with the Transparency International variable.

\begin{tabular}{|c|c|c|c|c|}
\hline \multirow{4}{*}{ Intercept } & (1) & (2) & (3) & (4) \\
\hline & No Corruption & PRSG & World Bank & Transparency \\
\hline & $7.821^{* * *}$ & $8.155^{* * *}$ & $8.698^{* * *}$ & $9.662^{* * *}$ \\
\hline & $(0.239)$ & $(0.292)$ & $(0.048)$ & $(0.660)$ \\
\hline \multirow{2}{*}{ CORR } & N/A & -0.382 & $-0.808^{* * *}$ & $-0.434^{* * *}$ \\
\hline & & $(0.234)$ & $(0.038)$ & $(0.066)$ \\
\hline \multirow[t]{2}{*}{ SIZE } & -0.006 & 0.003 & 0.002 & 0.019 \\
\hline & $(0.013)$ & $(0.009)$ & $(0.003)$ & $(0.013)$ \\
\hline \multirow[t]{2}{*}{ DEBT } & $0.199^{*}$ & $0.153^{*}$ & 0.005 & 0.012 \\
\hline & $(0.108)$ & $(0.088)$ & $(0.024)$ & $(0.111)$ \\
\hline \multirow{2}{*}{ MTB } & 0.011 & 0.006 & $5.6 \mathrm{E}-4$ & -0.002 \\
\hline & $(0.007)$ & (0.005) & $(0.001)$ & $(0.003)$ \\
\hline \multirow[t]{2}{*}{ SALESGR } & $0.020^{* * *}$ & $0.017^{* * *}$ & $-0.003^{* * *}$ & 0.009 \\
\hline & (0.005) & $(0.004)$ & $(0.001)$ & $(0.006)$ \\
\hline \multirow[t]{2}{*}{ R\&D } & $0.588^{* *}$ & $0.386^{* * *}$ & $0.072^{*}$ & 0.195 \\
\hline & $(0.237)$ & $(0.148)$ & $(0.037)$ & $(0.163)$ \\
\hline \multirow[t]{2}{*}{ ADV } & $-3.75^{* * *}$ & $-2.328^{* * *}$ & 0.033 & -1.585 \\
\hline & (1.416) & $(0.867)$ & (0.189) & (1.318) \\
\hline \multirow[t]{2}{*}{ EMPL } & $-10.665^{* * *}$ & $-11.236^{* * *}$ & $-1.337^{*}$ & -3.172 \\
\hline & (4.394) & $(4.031)$ & $(0.762)$ & (4.217) \\
\hline \multirow{2}{*}{ HIGHWAY } & 0.015 & -0.002 & $-5.27 E-5$ & -0.003 \\
\hline & $(0.036)$ & $(0.030)$ & $(0.009)$ & $(0.035)$ \\
\hline \multirow[t]{2}{*}{ GDP CAP } & $-0.211^{* *}$ & $-0.153^{* *}$ & -0.004 & -0.078 \\
\hline & $(0.089)$ & $(0.076)$ & $(0.011)$ & $(0.080)$ \\
\hline \multirow[t]{2}{*}{ WAGE } & $0.935^{* * *}$ & $0.782^{i * *}$ & 0.013 & $0.378^{*}$ \\
\hline & $(0.194)$ & $(0.160)$ & $(0.039)$ & $(0.215)$ \\
\hline \multirow[t]{2}{*}{ MFG } & -0.046 & -0.034 & $-0.028^{* *}$ & $-0.121^{* *}$ \\
\hline & $(0.048)$ & $(0.035)$ & $(0.013)$ & $(0.049)$ \\
\hline $\mathbf{N}$ & 293 & 277 & 144 & 206 \\
\hline $\mathbf{R}^{2}$ & 0.4827 & 0.4997 & 0.7915 & 0.6993 \\
\hline Model P-Value & $<0.0001$ & $<0.0001$ & $<0.0001$ & $<0.0001$ \\
\hline
\end{tabular}

It can be seen that the addition of any of the corruption variables improves the correlation coefficient, and all but PRSG are highly significant as predictors, in the expected negative sign (lower corruption correlates with less waiting to invest). The PRSG index, while just outside 
$10 \%$ significance, edges out the others in stability, with no sign changes for significant variables, and all significant variables staying significant. In contrast, the introduction of World Bank's index causes sales growth to switch from positive and significant to negative and significant. Transparency International's index causes most variables to lose significance, but does not cause any significant sign switching. The next table reports results for two probit models, one without any corruption variable and another with Transparency International's index introduced:

\begin{tabular}{|c|c|c|}
\hline & $\begin{array}{c}(1) \\
\text { No Corruption }\end{array}$ & $\begin{array}{c}(2) \\
\text { Transparency Intl. }\end{array}$ \\
\hline Intercept & $\begin{array}{l}-1.706 \\
(.)\end{array}$ & $\begin{array}{l}-4.970747 * * * \\
(1.974194)\end{array}$ \\
\hline CORR & N/A & $\begin{array}{l}1.310884 * * * \\
(0.4606846)\end{array}$ \\
\hline SIZE & $\begin{array}{l}0.1696185 * * * \\
(0.0623969)\end{array}$ & $\begin{array}{c}0.132951^{*} \\
(0.0735474)\end{array}$ \\
\hline DEBT & $\begin{array}{l}-1.039365^{*} \\
(0.5640707)\end{array}$ & $\begin{array}{l}-0.951253 \\
(0.5945325)\end{array}$ \\
\hline MTB & $\begin{array}{l}-0.0164936 \\
(0.0266875)\end{array}$ & $\begin{array}{l}-0.0169897 \\
(0.0273052)\end{array}$ \\
\hline SALESGR & $\begin{array}{c}0.008426 \\
(0.0589596)\end{array}$ & $\begin{array}{c}0.007944 \\
(0.0585998)\end{array}$ \\
\hline R\&D & $\begin{array}{l}-1.066818 \\
(0.828705)\end{array}$ & $\begin{array}{l}-1.20237 \\
(0.8913863)\end{array}$ \\
\hline ADV & $\begin{array}{c}-11.18272 * * * \\
(4.112753)\end{array}$ & $\begin{array}{c}-16.42197 * * * \\
(5.429204)\end{array}$ \\
\hline EMPL & $\begin{array}{l}3.805499 \\
(17.88422)\end{array}$ & $\begin{array}{r}3.87512 \\
(19.2791)\end{array}$ \\
\hline SEZ & $\begin{array}{l}1.199181 * * \\
(0.5695942)\end{array}$ & $\begin{array}{c}1.301215^{* *} \\
(0.6147238)\end{array}$ \\
\hline ENROLL & $\begin{array}{l}0.0071481 * * * \\
(0.0024579)\end{array}$ & $\begin{array}{l}0.0082351^{* *} \\
(0.0033538)\end{array}$ \\
\hline HIGHWAY & $\begin{array}{c}8.32 \mathrm{e}-06 \\
(7.16 \mathrm{e}-06)\end{array}$ & $\begin{array}{l}0.00002 * * \\
(9.24 \mathrm{e}-06)\end{array}$ \\
\hline RURAL ELEC & $\begin{array}{l}-0.0036409 * \\
(0.0019674)\end{array}$ & $\begin{array}{l}-0.0050725^{* *} \\
(0.0022724)\end{array}$ \\
\hline GDP CAP & $\begin{array}{l}0.0001187^{* *} \\
(0.0000595)\end{array}$ & $\begin{array}{l}0.0002054^{* * *} \\
(0.000074)\end{array}$ \\
\hline WAGE & $\begin{array}{l}-0.0001711 \\
(0.0001108)\end{array}$ & $\begin{array}{l}-0.0002739^{* *} \\
(0.000142)\end{array}$ \\
\hline $\mathbf{N}$ & 271 & 196 \\
\hline Psuedo- $\mathbf{R}^{2}$ & 0.2810 & 0.2893 \\
\hline Model P-Value & $<0.0001$ & 0.0003 \\
\hline
\end{tabular}


In most ways, the results for this model are better than for the timing model. First, not a single variable flipped signs when adding the corruption variable. This would indicate that our model is fairly stable. Secondly, the corruption variable is highly significant, and in the direction we would like it to be (i.e., less corruption encourages high equity investment). Thirdly, the addition of a corruption variable maintains other variables' significance, and enhancing it in

some cases. It also raises the pseudo- $\mathrm{R}^{2}$ score, though both are quite low. Finally, most included variables are of expected sign, with the exception of rural electricity consumption, which is both significant and of the opposite sign as expected.

\section{Conclusion}

The timing of investment models run in this experiment had mixed results. Adding corruption variables improved correlation coefficients, but saw some instability of other variables, which were often of an unexpected sign. Transparency International's corruption index performed the worst on all counts, while PRSG and World Bank each had greater measures of success maintaining variable significance and sign stability. In the cases of World Bank and Transparency International, the corruption variable attained high statistical significance, with p-scores at or below 0.01 . In the case of PRSG, results were outside conventional standards of significance, but approached 0.10 .

Results were much different in the case of the equity type model. While both PRSG and World Bank's indices were dropped due to multicollinearity, Transparency International's index not only found high significance in the expected sign, but kept the model stable and slightly improved significance overall for the control variables. Further, almost all variables were of their expected signs. The only tarnish on this experiment was a rather low pseudo- $\mathrm{R}^{2}$ of less than 
0.30. Overall I would call the experiment a success and would claim that there is evidence that lower perceptions of corruption have a positive relationship with a firm's likelihood of committing FDI as a wholly-owned subsidiary, a joint venture, a new plant, or an acquisition, rather than a mere sales office.

The usefulness of our corruption indices as they are now cannot be taken for granted. Certainly the fact that they are so poorly correlated to each other should cast doubt on their usefulness in the first place. However, due to the marginally positive results for the timing of entry model, and the generally even better results for the equity model, I remain hopeful about the prospect of continuing to use the indices for useful empirical results. 


\section{Sources}

Aizenman, Joshua and Mark M. Spiegel. "Institutional Efficiency, Monitoring Costs, and the Investment Share of FDI.” NBER Working Paper Series. November 2002.

Alvaro Cuervo-Cazurra. "Who Cares About Corruption?" Journal of International Business

Studies. November 2006, vol.37, iss.6, pp. 807-822.

Amiti, Mary and Beata Smarzynska Javorcki. "Trade Costs and Location of Foreign Firms in China.” International Monetary Fund Working Papers, March 2005.

Benassy-Quere, Agnesm Maylis Coupet, and Thierry Mayer. "Institutional Determinants of Foreign Direct Investment.” World Economy. May 2007, vol.30, iss.5, pp. 764-782.

Chen, Yung-Ming. “Determinants of FDI Mode Choice: Acquisition, Brownfield, and Greenfield Entry in Foreign Markets.” Canadian Journal of Administrative Sciences, September 2006, vol.23, iss.3, pp.202-220.

Cole, Matthew A., Robert J.R. Elliott, and Jing Zhang. “Corruption, Governance and FDI Location in China: A Province-level Analysis.” Journal of Development Studies, October 2009, vol.45 iss.9, pp. 1494-1512.

Egger, Peter and Hannes Winner. "How Corruption Influences Foreign Direct Investment: A Panel Data Study.” Economic Development and Cultural Change. 2006, vol.54, iss.2, pp. $459-86$.

Fung, K.C., Alicia Garcia-Herrero, Hitomi Izaka, and Alan Siu. "Hard or Soft? Institutional Reforms and Infrastructure Spending as Determinants of Foreign Direct Investment in China.” The Japanese Economic Review, December 2005, vol. 56, iss. 4, pp. 408-416. 
Gao, Ting. "Labor Quality and the Location of Foreign Direct Investment: Evidence from China." China Economic Review, February 2005, vol.16, iss.3, pp. 274-292.

Globerman, Steven and Daniel Shapiro. "Governance Infrastructure and US Foreign Direct Investment.” Journal of International Business Studies, January 2003, vol.34, iss.1, pp.19-39.

Habib, Mohsin and Leon Zurawicki. "Corruption and Foreign Direct Investment.” Journal of International Business Studies. 2002, vol.33, iss.2, pp. 291-307.

Havrylchyk, Olena and Sandra Poncet. "Foreign Direct Investment in China: Reward or Remedy?” The World Economy, October 2007, vol.30, iss.11, pp. 1662-1681.

Hong, Junjie. "Firm-specific Effects on Location Decisions of Foreign Direct Investment in China's Logistics Industry.” Regional Studies, July 2007, vol.41, iss.5, pp. 673-683.

Hong, Junjie. "WTO Accession and foreign direct investment in China." Journal of Chinese Economic and Foreign Trade Studies, January 2008, vol.1, iss.2, pp. 136-147.

Kawai, Norifumi. "Locational Strategies of Foreign Investors in China: Evidence from Japanese Manufacturing Multinationals.” Global Economic Review, June 2009, vol.38, iss.2, pp. $117-141$

Liu, Tianshu. "Impact of Regional Trade Agreements on Chinese Foreign Direct Investment." The Chinese Economy, September-October 2008, vol:41, iss.5, pp. 68-102.

Paul, Donna and Rossitza Wooster. Working title. Working Paper, 2010. 
Quazi, Rahim. "Economic Freedom and Foreign Direct Investment in East Asia." Journal of the Asia Pacific Economy, August 2007, vol.12, iss.3, pp.329-344.

Raff, Horst and Michael J. Ryan. "Firm-Specific Characteristics and the Timing of Foreign Direct Investment Projects.” Review of World Economics, April 2008, vol.144, iss.1, pp. $1-31$.

Shapiro, Daniel, Yao Tang, and Cathy Xuejing Ma. "Mode of Entry and the Regional Distribution of Foreign Direct Investment in China." Journal of Chinese Economic and Business Studies, 2007, vol. 5, iss. 3, pp. 261-277.

Straub, Stephane. "Opportunism, Corruption, and the Multinational Firm's Mode of Entry." Journal of International Economics. March 2008, vol.74, iss.2, pp. 245-263.

Sun, Qian, Wilson Tong, and Qiao Yu. "Determinants of Foreign Direct Investment Across China." Jounal of International Money and Finance, February 2002, vol.21, iss.1, pp. 79113.

Yu, Chia-Feng, Ta-Cheng Chang, and Chinn-Ping Fan. "FDI timing: Entry cost subsidy versus tax rate reduction.” Economic Modeling, March 2007, vol.24, iss.2, pp.262-271. 